\title{
IS THERE A NEXUS BETWEEN SOCIAL ENTREPRENEURSHIP AND THE EMPLOYABILITY OF GRADUATES?
}

\author{
Bulelwa MANDYOLI*, Chux Gervase IWU**, Zinzi NXOPO*** \\ Cape Peninsula University of Technology, Faculty Business and Management Sciences, South Africa \\ *e-mail: bulelwamandyoli@gmail.com \\ **e-mail: iwuc@cput.ac.za \\ ***e-mail: nxopoz@cput.ac.za
}

\begin{abstract}
Social entrepreneurs have, in several ways, been regarded as engines of intense socioeconomic development. They are also famous for intervening with projects for society's problems that are often either inadvertently ignored or inadequately managed by mainstream society. The issue of graduate employability has gained increased tension around the world especially in emerging markets such as South Africa. Currently, suggestions are that considering the avowed contribution of social entrepreneurs, it may be worthwhile to start examining how they can assist with graduate employability in South Africa. This paper, therefore, takes an exploratory yet focused scrutiny of the social entrepreneurship ecosystem to find out the likelihood of social entrepreneurs participating in programs that prepare students for the workplace, thereby reducing graduate unemployability. This is a conceptual paper that has benefitted from an extensive review of literature. Conclusions are drawn therefrom to suggest that opportunities exist for social entrepreneurs to provide practical, project-based learning opportunities for college and university students so that by the time they graduate, they have attained reasonable work-readiness levels that stand them in good stead for employment. While the authors propose an intensive empirical study of the subject matter, we are equally positive that this paper may be used to advance the current platforms of engagement of the role of social entrepreneurs or grow innovative methods that provide graduates with a better chance to be successful in the working environment. In short, this paper calls for sustained discussions on how social entrepreneurs can improve graduate employability.
\end{abstract}

Keywords: socioeconomic development, social entrepreneurs, enterprise education, South Africa, graduate unemployment, graduate attributes, social enterprise.

\section{Introduction}

Graduate unemployment is common around the world especially in developing countries. And this has been attributed to a receding Western economy and a dearth of employability skills among graduates. Little wonder why numerous studies have been conducted across the globe to figure out specifically why this remains unsolvable. A few brave graduates take the path of entrepreneurship while many others rely on government and the private sector for paid employment.

It is common knowledge that government alone cannot provide the much needed jobs for every graduate in any society. The private sector, on the other hand, is known to have very stringent conditions for employment. Some of these conditions are very restrictive and demanding for fresh college/university graduates who are considered ill-equipped for the world of work. It is on this basis that renewed calls have been made to find out if there are other ways to ensure that by the time a college or university student graduates, he/she is ready for the workplace. Fingers have already started pointing at social entrepreneurs whose real value in transforming communities is yet to be fully explored (Mair \& Marti, 2006; Welsh, 2012).

Entrepreneurship is "the innovative use of resource combinations to pursue opportunities aiming at the creation of organizations and or practices that yield and sustain social benefits" (Mair \& Noboa, 2014). This definition signifies the use of entrepreneurial approach to solve certain social problems (Meyer \& Gauthier, 2012). Practitioners of the social entrepreneurship approach are those whom Ashoka (2012) and Abu-Saifan (2012, p.24) believe are "individuals 
with innovative solutions to society's most pressing social problems' further suggesting that 'they are both visionaries and ultimate realists; concerned with the practical implementation of their vision above all else'."

Social entrepreneurs are "individuals or organizations engaged in entrepreneurial activities with a social goal" (Bosma \& Amoros, 2013, p.242), implying that the social entrepreneurial approach can be used to improve the efficiency and strength of existing entrepreneurship programs carried out by volunteer organizations, government sectors, business, and non-governmental organizations. Bosma and Amoros (2013) furthermore highlight that social entrepreneurship is a process of activities that includes discovery, evaluation, and trailing of opportunities that does not have to result in a new venture creation: the initiation and launch of both formal and informal organizations in pursuit of a social goal.

One of the millennium development goals (MDGs) was to achieve improved employability of citizens. This indicates that employability of individuals is important in socioeconomic development. It is assumed, therefore, that governments around the world are under pressure to reduce the levels of unemployment. In the case of South Africa, government's commitment is evident in several interventions and policies that aim at closing the gaps in unemployment and poverty.

These interventions are in the form of small, medium, and micro enterprises support structures and initiatives such as Small Enterprise Development Agency, Industrial Development Corporation, National Development Agency, National Empowerment Fund, National Youth Development Agency, South African Women Entrepreneurs' Network, Technology for Women in Business, Small Enterprise Finance Agency, the Land Bank, Micro-Agricultural Financial Institution of South Africa, the newly created Department for Small Businesses, and several others.

There are also some public-private initiatives such as the Sector Education and Training Authority skills development programs (e.g., study bursaries), the National Skills Development Agency, and the National Skills Fund. Despite these efforts, unemployment continues to rise. The problem of unemployment is even worse for those who have attained higher education. According to South Africa's Higher Education Policy (2012), the problem of graduate employability remains a high priority for higher education policy makers, thus emphasizing the importance of skills needed by graduates to face the challenging and increasingly flexible labor market.

Graduates in South Africa face increasing levels of unemployment even though there have been several interventions by both government and private organizations. The question that begs an answer is how else can this seemingly endless problem be solved? According to Graduate Market Trends (2011, p.4), organizations nowadays search for those who are adaptable, innovative, original, compliant, and intelligent problem solvers. Altbeker and Storme (2013) affirm that graduates face challenges with regard to securing employment.

In June 2012, a City Press article on graduate unemployment warned that "a university degree or diploma no longer guarantees employment for young South Africans as hundreds of thousands of them struggle to obtain employment." The reason for this can be viewed from the perspectives that employers anticipate graduates to have practical work experience on or after their degree, including the ability to demonstrate a range of broader skills and characteristics that include teamwork, communication, leadership, critical thinking, problem solving, and managerial abilities (Moleke, 2010).

Several studies have focused on graduate unemployment as well as the related causes of unemployment in South Africa. These studies paid attention to employment in the formal sector. Our paper derives its uniqueness from its scope, that is, social entrepreneurs. In this paper, a theoretical examination of the likely role(s) of social entrepreneurs in improving graduate employability is undertaken. In so doing, one may disclose their potential or lack thereof in reducing the levels of unemployment, specifically their likely contribution to graduate employability.

To determine these roles, we start by looking at the literature that has been published by entrepreneurship theorists and practitioners to advance the concept of social entrepreneurship including its different types and capacity for socioeconomic development. We also interrogate graduate employment in South 
Africa while highlighting the different employability characteristics and the probable cause of graduate unemployability in South Africa. Thereafter, we explore the critical issue of graduate employability through social enterprise. We conclude this paper by calling for a further investigative engagement of the subject of social entrepreneurship and its capability to improve graduate employability on South Africa.

\section{$2 \quad$ Method}

Different methods of conducting research exist. Some of the methods are more apt for certain disciplines, while there are also some which have multidisciplinary essence.

In social sciences, the traditional literature review method is often used (see Petticrew \& Roberts, 2008; Victor, 2008).

The object of this paper is to examine the likely role(s) of social entrepreneurs in improving graduate employability. This is a novel study and, therefore, requires an approach that allows for the inclusion of both qualitative and quantitative data in order to facilitate a better understanding of this novel and noble idea.

The method adopted in this study is the traditional literature review. Its epistemological orientation of interpretivism serves perhaps as the foremost method for conducting studies in social science disciplines. According to Rozas and Klein (2010, p.387), the method offers "a valid and important way to identify existing patterns and gaps ..." and draws "... not only on quantitative ... but also qualitative studies."

\section{$3 \quad$ Literature review}

The concept of social entrepreneurship has gained such traction because many traditional civil society organizations such as non-profit, non-governmental organizations have begun to identify themselves as social enterprises (Travedi, 2010) and to create community benefit irrespective of ownership or legal structure and with varying degrees of financial independence, innovation, and social transformation
(Brouard \& Larivet, 2011). Trivedi (2010) also adds that social entrepreneurs create and use economic profit as a means of solving social problems.

Bacq and Janssen (2011) affirm that "the social entrepreneur is a mission-driven individual who uses a set of entrepreneurial skills to deliver a social value to the less privileged." This characterization according to Bacq and Janssen distinguishes social entrepreneurs from profit-oriented entrepreneurs.

For instance, social entrepreneurs are described as mission-driven individuals who are committed to delivering a social value to the needy. Other distinguishing elements include the following:

- They bring their entrepreneurial flair to bear upon the work they do using a combination of characteristics that set them apart from other types of entrepreneurs.

- They act within entrepreneurially oriented organizations that have a strong culture of innovation and openness.

- They act within financially independent organizations that plan and execute earned-income strategies with the objective of delivering the intended social value while remaining financially selfsufficient. In this regard, financial self-sufficiency is achieved by blending social and profit-oriented activities to achieve self-sufficiency, reduce reliance on donations and government funding, and increase the potential of expanding the delivery of proposed social value.

Santos (2012, p.344) argues that social entrepreneurs are economic agents who, because of their motivation, can create value without concern for profit but specifically targeting a disadvantaged population. In essence, Santos claims that social entrepreneurship is not specifically about creating market mechanisms or securing government subsidies or creating a social enterprise but about crafting effective and sustainable solutions using whatever combination of institutional means necessary. This characterization is indeed compatible with the view of social entrepreneurship as an umbrella concept with plenty of room for different initiatives to tackle social problems. And one of those is the issue of graduate employability. 


\section{$4 \quad$ Types of social entrepreneurs}

Considering that different characterizations have been adapted for the term social entrepreneur, it is not unusual to find that "different types of social entrepreneurs exist, addressing specific social problems in their own ways and within their own realms" (Zahra, Gedajlovic, Neubaum, \& Shulman, 2009). Nonetheless, the similarities and differences among the broad range of social entrepreneurship practitioners can be located within three types of social entrepreneurs, namely, social bricoleurs, social engineers, and social constructionists. Smith and Stevens' (2010) description of these types of social entrepreneurs are as follows:

- Social bricoleurs work with communities to identify their real issues and find solutions to those issues. Their affinity to the communities they operate in facilitate the identification and resolution of the local social issues. Zahra, et al. (2009) affirm that "without them, many indiscernible or unrecognizable social needs would remain unaddressed." In short, entrepreneurs who find and use opportunities as well as resources found in their local domains for the benefit of the local community are referred to as social bricoleurs. Two organizations - Treatment Action Campaign and Section 27 - stand out in South Africa as good examples of social bricoleurs. These social entrepreneurs champion the interest of those living with human immunodeficiency virus infection and acquired immune deficiency syndrome (HIV/Aids) and those parents who insist on good quality education for their children.

- Social engineers focus on large-scale, complex issues that are often beyond the capacity of a community to manage on its own. They identify systemic problems such as unemployment or entrenched poverty within a social system and then find ways to address them. Social entrepreneurs are able to achieve this by "fracturing existing and often dominant institutions and replacing them with more socially efficient ones" (Zahra et al., 2009). A name that is regularly mentioned as a classic example of a social engineer is the internationally acclaimed microfinancier, Yunus Mohammed. Through his Grameen bank, he provides credit facilities to indigent people of Bangladesh without necessarily seeking collateral but expecting recipients to be trustworthy and creative in the way they make use of the funds they receive. Essentially, Yunus Mohammed has transformed the hitherto orthodox practice of this sector.

- Social constructionists are highly opportunity driven, but not in the sense of a commercial entrepreneur. They identify and simply pursue opportunities with the goal of creating social wealth. Social constructionists identify opportunities, develop them to become successful, and then use them to resolve those social needs that are ineffectively addressed by existing institutions. A good example of a social constructionist is the Open Society Foundation. This brainchild of George Soros aims to protect and improve the lives of people in marginalized communities and "to build vibrant and tolerant societies whose governments are accountable and open to the participation of all people" (Open Society Foundation).

The main objective of this paper is to find out the likely role of social entrepreneur's in improving graduate employability in South Africa. Thus the authors are more inclined to believe that social entrepreneur's develop and validate sustainable solutions to problems (Santos, 2012) that have a significant impact on how to improve and sustain societies (Dempsey \& Sanders, 2010).

\section{The role of social entrepreneurs}

The focus of this paper is to understand how social entrepreneurs can contribute to graduate employability. Therefore, it is necessary to reflect or review literature on the role of social entrepreneurs.

Karanda (2012) assumes that social entrepreneurs have a unique critical bottom line by which to extend their success. This unique critical bottom line hovers around improved access to health care, more effective education, poverty reduction, provision of a cleaner environment, and protection of abused children. Education, for instance, is the main vehicle used by the community to develop new generations and to reform education to affect knowledge. 
According to Jafta (2013), social entrepreneurs can help solve some of South Africa's developmental problems and address the lack of social unity. They form and manage initiatives to achieve social change.

Sivanathanu and Bhise (2013, p.1) are of the opinion that social entrepreneurs play the role of social change in the society by:

- adapting a mission to formulate and sustain social value,

- recognizing and persistently chasing new opportunities to serve that mission,

- engaging in the process of continuous innovation, adaption, and learning,

- acting boldly without being limited by resources currently in hand.
Essentially, the key motivation of social entrepreneurs is to take action against a community's problem without the intention of profiting financially, that is, they prioritize more on serving the needs and wants of the community in a more ingenious way. This is an indication that social entrepreneurs differ from profit-oriented entrepreneurs.

According to Santos (2012), a dominant difference between commercial entrepreneurship and social entrepreneurship is that social entrepreneurs are determined to generate value for society. Abu-Saifan (2012) identifies the unique characteristics of profitoriented entrepreneurs and social entrepreneurs mostly found in both types of entrepreneurs - as shown in Table 1.

Table 1. Unique and common characteristics of profit-oriented entrepreneurs and social entrepreneurs (source: Abu-Saifan, 2012, p.25)

\begin{tabular}{|l|l|l|}
\hline $\begin{array}{c}\text { Unique characteristics } \\
\text { of the profit-oriented entrepreneur }\end{array}$ & $\begin{array}{c}\text { Characteristics common } \\
\text { to both types }\end{array}$ & $\begin{array}{c}\text { Unique characteristics } \\
\text { of the social entrepreneur }\end{array}$ \\
\hline - High achiever & - Innovator & Mission leader \\
- Risk bearer & - Dedicated & Emotionally charged \\
- Organizer & - Initiative thinker & - Change agent \\
- Strategic thinker & - Leader & - Opinion leader \\
- Value creator & - Opportunity alert & - Social value creator \\
- Holistic & - Persistent & - Social alert \\
- Arbitrageur & - Committed & - Manager \\
& & - Visionary \\
& & Highly accountable \\
\hline
\end{tabular}

In the non-profit perspective, opportunities are not joined to the creation of wealth for owners but fairly linked to the necessity to support a social purpose yet remaining financially sustainable (Moss, Short, Payne \& Lumpkin, 2010).

According to Kirkwood and Walton (2010), the purpose of a social enterprise is to deal with foremost social issues that may have been inadequately catered for or escaped the attention of government. Essentially, social entrepreneurs are viewed as those with the unique capacity to spot and tackle complex social issues rather than leaving societal needs to the government or the private sector. 
Several descriptions have been put forward for the term graduate. These range from holders of a bachelor or higher degree from a university (Altbeker \& Storme, 2013) and people with college education who are targeted by companies in their graduate recruitment programs (Pauw, Bhorat, Goga, Ncube, \& Van der Westhuizen, 2011) to students who have graduated (Letseka, Cosse, Breir \& Visser, 2010).

Nevertheless, we are inclined to define a graduate, with reference to this paper, as a degree holder (including postgraduate qualification) without reference to the institution where the qualification was obtained. We are convinced that this is a more apt definition considering that studies have indicated the high likelihood of employment for people with college/university degrees.

Albeit, considering the high levels of graduate unemployment in South Africa, there is serious doubt whether this is the true position (Oosthuizen, 2005). It is even argued that graduate unemployability is the result of a lack of qualifications in Engineering and Science, which Breier and Erasmus (2009) have squarely placed at the door of the segregated educational system that did not allow the majority of South African's to pursue studies in these disciplines.

The term employability means different things to different scholars and practitioners. In fact, one is yet to find consensus in literature as to how to definitively characterize this term. According to Coetzee and Esterhuizen (2010, p.3), "employability refers to those proactive career behaviors and abilities that allow people to obtain or generate work through optimal use of both occupation-related and career meta-competencies." Lowden, Hall, Elliot, and Lewin (2011) add "while there are variations in the classification of employability, there is a broad understanding of what qualities, characteristics, skills and knowledge constitute employability both in general and specifically for graduates."

Nonetheless, scholars are in agreement that the term simply speaks to attributes that suggest ones capacity to be hired for a job. Minten (2010), for instance, characterizes employability as the competence of attaining and continuing to accomplish work, the aptitude to act independently in the work place to succeed by means of sustainable employment. Individual employability relates to understanding, attitudes, and skills that an individual retains and the way in which they use these possessions when they are presented to potential employers in a specific situation such as the labor market. This fits Barries' (2006) interpretation of the requisite credentials for employability, which include work-integrated learning modules and practical applications for students to gain experience in the work environment and identify certain skills in practice.

The above descriptions provide a foundation for understanding the concept of employability; it is clear that employability is the level to which workers have abilities that employers view as excellent. Some of these abilities are captured in Table 2 (courtesy of McQuaid and Lindsay, 2005).

According to Cape Higher Education Consortium (CHEC, 2010, p.5), South Africa has experienced a major development in the figures of unemployed youth together with matriculants and university level graduates. The issue of unemployed graduates is increasing globally and not exclusive to South Africa. There is enormous literature on the subject with numerous studies based on tracer and longitudinal assessments of young people as they pass through higher education into employment.

The number of graduates who are unemployed continues to rise in South Africa. This is viewed seriously, especially given that unemployment is steadily climbing up to $26 \%$. During the first and second quarters of 2013, unemployment increased by more than 100, 000 (StatsSA, 2013).

As StatsSA further reveals, a large number of those who were unemployed in the second quarter of 2013 comprised those who did not complete high school education, thus suggesting that the successful completion of high school as well as obtaining a tertiary qualification could be a panacea for unemployment. But as Moleke (2006) posits, several other factors impede employability. These include institution attended, field of study, race, and gender. 
Table 2. Necessary abilities for employability (source: McQuaid and Lindsay, 2005, p.209 [adapted])

\begin{tabular}{|c|c|c|}
\hline Individual Factors & Personal Circumstances & External Factors \\
\hline $\begin{array}{l}\text { Employability skills and attributes } \\
\text { - Essential attributes } \\
\text { Basic social skills, honesty and integrity, } \\
\text { basic personal presentation, reliability, } \\
\text { willingness to work, understanding } \\
\text { of actions and consequences, positive } \\
\text { attitude to work, responsibility, } \\
\text { and self-discipline. } \\
\text { - Personal competencies } \\
\text { Proactivity, diligence, self-motivation, } \\
\text { judgment, initiative, assertiveness, } \\
\text { confidence, act autonomously. } \\
\text { - Basic transferable skills } \\
\text { Prose and document literacy, writing, } \\
\text { numeracy, and verbal presentation. } \\
\text { - Key transferable skills } \\
\text { Reasoning, problem solving, adaptability, } \\
\text { work-process management, teamwork, } \\
\text { personal task and time management, } \\
\text { functional mobility, basic information } \\
\text { communication technology (ICT) skills, } \\
\text { basic interpersonal and communication } \\
\text { skills, and emotional and esthetic custom- } \\
\text { er service skills. } \\
\text { - High-level transferable skills } \\
\text { Teamwork, business thinking, commercial } \\
\text { awareness, continuous learning, vision, } \\
\text { job-specific skill, and enterprise skills. } \\
\text { - Quabor markifications } \\
\text { Formal academic and vocational qualifica- } \\
\text { tions and job-specific qualifications. } \\
\text { of unemployment/ inactivity, and balance } \\
\text { of work history. Work knowledge base } \\
\text { Work experience, general work skills } \\
\text { and personal aptitudes, commonly valued } \\
\text { transferable skills such as driving, } \\
\text { and occupation-specific skills. } \\
\text { tont } \\
\text { tomer }\end{array}$ & $\begin{array}{l}\text { Household circumstances } \\
\text { - Direct caring } \\
\text { responsibilities } \\
\text { Caring for children, elderly } \\
\text { relatives, etc. } \\
\text { - Other family and } \\
\text { caring responsibilities } \\
\text { Financial commitments to } \\
\text { children or other family } \\
\text { members outside the indi- } \\
\text { vidual's household, emo- } \\
\text { tional and time } \\
\text { commitments to family } \\
\text { members or others. } \\
\text { - Other household } \\
\text { circumstances } \\
\text { The ability to access safe, } \\
\text { secure, affordable, and } \\
\text { appropriate housing. }\end{array}$ & $\begin{array}{l}\text { Demand factors } \\
\text { - Labor market factors } \\
\text { Level of local and regional or other } \\
\text { demand, nature of and changes in } \\
\text { local and regional demand (required } \\
\text { skill levels, occupational structure } \\
\text { of vacancies, sectors where demand } \\
\text { is concentrated), location, centrality } \\
\text { or remoteness of local labor markets } \\
\text { in relation to centers of industry } \\
\text { or employment, level of competition } \\
\text { for jobs, actions of employers' com- } \\
\text { petitors, changing customer prefer- } \\
\text { ences, etc. } \\
\text { - Macroeconomic factors } \\
\text { Microeconomic stability, medium- } \\
\text { to long-term business confidence, } \\
\text { level and nature of labor demand } \\
\text { within the national economy. } \\
\text { - Vacancy characteristics } \\
\text { Remuneration; conditions of work; } \\
\text { working hours and prevalence } \\
\text { of shift work; opportunities } \\
\text { for progression; extent of part-time, } \\
\text { temporary, and casual work; } \\
\text { and availability of “entry-level" } \\
\text { positions. } \\
\text { - Recruitment factors } \\
\text { Employers' formal recruitment } \\
\text { and selection procedures, employers' } \\
\text { general selection preferences (e.g., } \\
\text { for recent experience), employers' } \\
\text { search channels (methods of search- } \\
\text { ing for staff when recruiting), dis- } \\
\text { crimination (e.g., on the basis of age, } \\
\text { gender, race, area of residence, } \\
\text { disability, unemployment duration), } \\
\text { form and extent of employers' use } \\
\text { of informal networks, and demanding } \\
\text { only appropriate qualifications } \\
\text { or credentials. }\end{array}$ \\
\hline
\end{tabular}




\section{Potential causes of graduate unemployment}

According to Oluwajodu, Blaauw, Greyling, and Kleynhans (2015), unemployment is a high priority in South Africa. They also acknowledge reduction in economic welfare as well as brain drain as some of the consequences of unemployment in South Africa.

Oosthuizen, Kalie, and Carlene (2006) believe that graduate unemployment is a feature of several factors, namely,

- Qualification obtained and field of study. In today's increasingly complex business environment, organizations are more inclined to seek candidates with the right credentials for their core business. In most cases, one finds that the core business needs of organizations require mostly scarce skills such as Engineering and Science. In fact, Moleke (2006) makes a case for Engineering as field of practice that teaches relevant job-specific skills, which provide the fresh graduate the opportunity to do well at his/her job. Sadly, graduates with humanities and arts qualifications may take a longer period to secure employment because employers may be less certain about their capabilities (Moleke, 2006). On the basis of this, it is not surprising to find that the employment prospects of graduates with qualifications that are not in demand are shattered.

- Quality of education. A common debate among scholars and industry experts is that the quality of education in South Africa is progressively going down and this is reflected in poor pass rates of students at tertiary institutions. Many reasons have been put forward for this, including quality issues in basic education in South Africa. Worse still, the segregated education system that was available to the majority of the citizens during the apartheid era is still considered a major reason for poor performance in many tertiary institutions. As a result, employers hesitate to go on campus recruitment drives in historically black institutions. In agreement with this are Oluwajodu et al. (2015) whose sample of unemployed group comprised graduates of University of Fort Hare, University of Zululand, and University of Limpopo.
- Sustained discrimination. The unequal education system mentioned earlier could have roots in the unfortunate skewed employment data that seems to favor Whites and a few Asian and Colored South Africans. It can be argued that the skewed education system denied the majority of the citizens' opportunities for them to obtain employability skills, which include, among others, workplace readiness skills.

According to the National Film and Video Foundation (NFVF, 2009), to get a job with a qualification in the Arts may be demanding, considering that one is expected to have attained some work experience before accessing most jobs within film, music, and even social sciences. For instance, in the film industry, a directing role requires some experience. In the same vein, taking up the role of a creative officer is a long-term achievement and as a result may not be that enticing to remain in the profession for too long. It is, therefore, not surprising that substantial unemployment and unequal earnings characterize the South African labor market, with the youth excessively affected (StatsSA, 2013) leading to a reliance on social grants - including old age, child support, disability, foster care, care dependency, and grant-inaid for income (Western Cape Government, 2013).

\section{Graduate employability through social enterprise}

The argument around the employability of graduates is not a new one; in fact, it has been the issue of extensively ranging academic research for nearly three decades (Atwood, 2010). According to Bruns (nd), "most graduates lack essential experience of the work place. Their training has not been sufficiently relevant to the requirements of organizations. For graduates to compete in the highly competitive world of work, organizations in various industries have resorted to on-the-job training." Weddle (2010) adds "In the past, employers were willing to hire those who had modest skills and train them to perform a job. Today, they will only employ individuals who have all of the skills to do a job and the state-ofthe-art knowledge required to use those skills effectively on-the-job." 
According to Owens and Tibby (2014), graduates require the skills, abilities, and qualities to allow them to be effective in this shifting global economic environment. Progressively, employers believe graduates to be innovative, adaptable, and flexible and have an enterprising mindset. Enterprise education supports employability by empowering students to develop the characteristics, attributes, and skills that will enable them to make effective contributions to the economy and society. Enterprise education evidently links to employability and, as such, has to be at the core of employability strategies.

Wilson (2012) defines enterprise education as the process of preparing graduates with an improved capacity to generate ideas and the skills to make them happen. This prepares graduates with characteristics, capabilities, and skills that develop their employability and empower them to be entrepreneurial in a range of settings including employment. Helyer (2010) makes a case for experiential learning as ancillary to this process by stating that learning and doing cannot be separated and, therefore, students who simply focus on their degree studies without spending time in the workplace are unlikely to develop the skills and interest that graduate em- ployers are looking for (Birchall, 2013). However, Cooper, Orrell, and Bowden (2010, p. 62) also affirm this view that it is not enough for graduates to simply experience the workplace inactively, they need to actively participate in order to learn. Essentially, learning is the product of graduates' efforts to understand and transform their experience in a way that it makes sense to them.

\section{Graduates' attributes}

It is common to find various explanations for the causes of graduate unemployment in South Africa. A number of these have been attributed to unemployability perhaps resulting from qualification obtained, institution attended, and even work experience. Some studies have, however, paid attention to skills and attributes that facilitate employment. For instance, Harvey and Green (2004, p. 185) put forward what employers have indicated as the most wanted graduate skills groups in rated order of employers' preference (see Table 3).

Table 3. Critical graduate attributes (source: Harvey and Green, 2004, p.185)

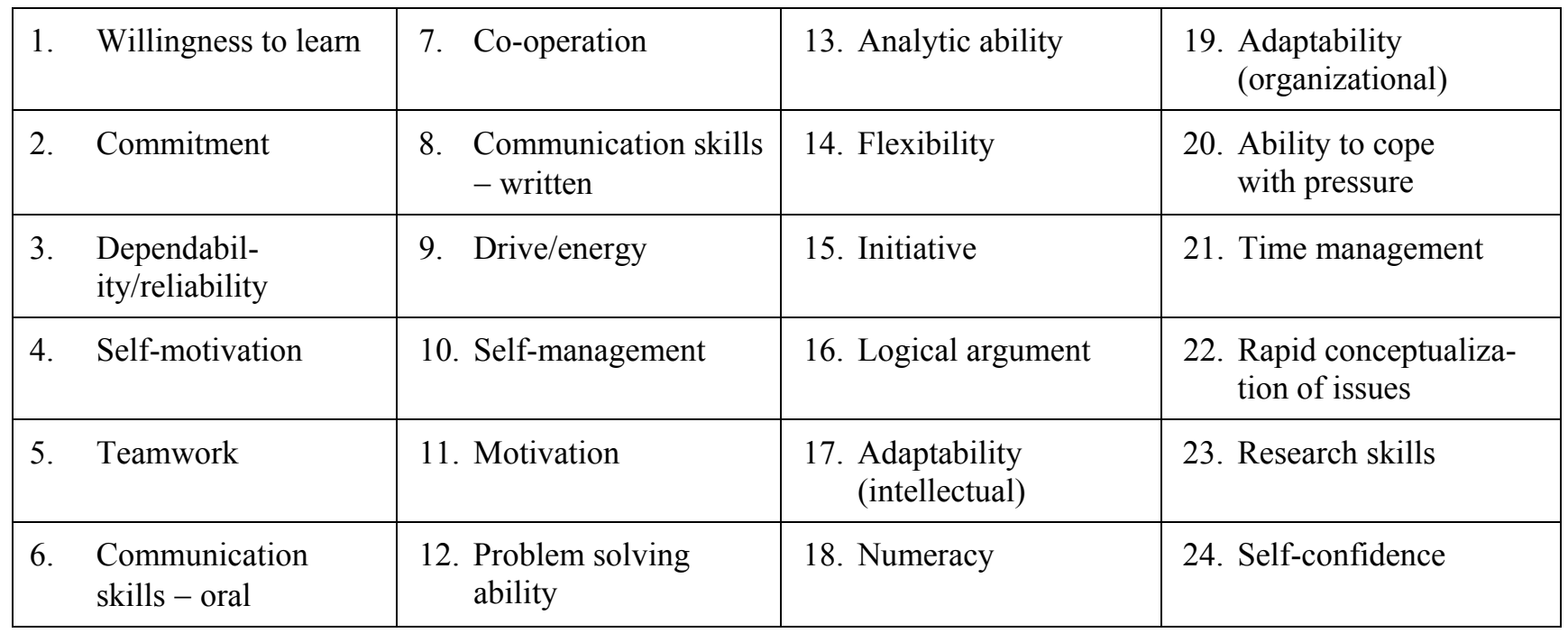

Griesel and Parker (2009) instead focus on four main categories of skills and attributes that employers look out for to include basic skills, intellectual ability, workplace skills, applied knowledge and interactive skills. 
CIHE (2010, p.9) acknowledge seven important necessities for graduate employability to include subject-specific knowledge, analytical research/ technical skills, maturity, thinking/problem solving skills, new ideas and capability to aid innovation, high potential, and future leadership potential. Gartland and Wood (2008), on the other hand, recognize that to improve employability and consequently enhance graduate attributes will require "increasing levels of conceptual, analytical and appraisal skills from undergraduates and master's-level students" with lessons that focus on, among others, "originality and the ability to deal with complex issues and make sound judgments in absence of complete data."

Coetzee, et al. (2012, p.10) concludes that it is very important for graduates to have personal skills such as:

- task management and problem solving - focusing on achieving objectives using analytical and conceptual thinking, collecting information to support problem solving and decision making,

- working with others - making use of logical and rational arguments to convince others and building positive relationship,

- self-awareness - taking responsibility for own development, earning and experiences, dealing with pressure and emotions.

Interestingly, Oluwajodu, et al. (2015) are of the view that "South African graduates are often unsuccessful in the recruitment phase, because they lack some of the required skills."

\section{Discussion}

Although we have found some papers that have reported the impact of social entrepreneurs on socioeconomic development, we are yet to find any evidence that makes a direct reference to how they can improve graduate employability. This claim of ours is not specific to South Africa using the data we have assembled from other studies. It is clear anyway that social entrepreneurs add value to socioeconomic development through their "charity" efforts and the provision of employment to community members (Malunga, Iwu, \& Mugobo, 2014). While these roles played by social entrepreneurs are noble, the crux of this paper, which is to understand how social entrepreneurs can improve graduate employability, is yet to be resolved. Judging from the contributions of Owens and Tibby (2014) and Wilson (2012) and Heyler (2010), we deduce that social entrepreneurs can demonstrate their efforts at reducing graduate unemployability by offering opportunities to university/college students and graduates to participate in what Owens and Tibby (2014) refer to as enterprise education. This, in our opinion, will comprise elements of work-integrated learning, job shadowing, experiential learning, and community engagement. It is hoped that these will not only build career management competencies in graduates but also improve their employability.

According to Jackson and Wilton (2016), one of the formidable ways of nurturing career management competencies in undergraduates is through workintegrated learning, which enhances students' understanding of the expected skills including how to perform on a job.

Work-integrated learning is considered necessary owing to the continued economic uncertainty and a highly competitive labor market (Ross, 2012; Tomlinson, 2012). Therefore, it is necessary to have employers assisting in the development and enhancement of employability opportunities for graduates by providing work readiness opportunities that bring real issues of the workplace to the attention of those who participate in work-integrated learning.

The concerns of Cleary, Horsfall, Muthulakshmi, Happell, and Hunt (2013) regarding a lack of managerial support in the workplace for those on workintegrated learning projects could serve as an excellent opportunity for social entrepreneurs. We posit this argument on the strength of our understanding that for-profit organizations, timelines, and other exigencies of business may not permit those who are assigned the responsibility of managing those on work-integrated learning to properly provide mentoring and other support they need.

Experiential learning means providing students with the opportunity to gain exposure, outside the classroom, to concepts that are taught in school. This could be in the form of simulations, field visits to organizations, and conducting small assignments for 
organizations (Luppino, 2007; Hindle, 2002; Duarte \& Hodge, 2007; Mustar, 2009). Austin and Rust (2015) refer to it as a hands-on experience that can include service learning, applied learning in the discipline, co-operative education, internships, study abroad, and experimental activities.

Job shadowing simply means allowing someone to observe a more experienced person executing his/her daily roles and responsibilities. Mader, Mader, and Alexander (2015) describe it as a "way for [the] youth to become aware of the world-ofwork through programs sponsored by schools or social organizations."

These propositions of ours have been widely researched and empirically suggested as likely buffers of work readiness of students but not in relation to social entrepreneurs. What has been suggested mostly in extant literature on enterprise education is a triad of engagement involving community, students/institutions of higher learning, and an organization (either public or private). An opportunity exists here for social entrepreneurs to champion enterprise education projects of colleges/universities by providing hands-on training opportunities for students to understand how problems are solved in the real world and so on. In this case, social entrepreneurs are in touch with colleges and universities, thereby they can make input into the curricula of schools.

Currently, evidence from South African studies suggests that mostly profit-oriented organizations are the ones that participate in these programs. It is believed that these programs serve as their corporate social responsibility effort. In fact, the Cell-C Take a Girl Child to Work program is hailed as a credible opportunity for young girls in high schools to be exposed to a variety of career options. Several organizations take this initiative seriously as they seek the support of schools to nominate participants. It is not yet known how far this program has aided young girls in preparing for a career after school. What this boils down to is that to date, there is hardly any empirical evidence in academic literature that social entrepreneurs, specifically in South Africa, add value to graduate employability.

\section{Conclusion}

The rising unemployment levels in South Africa have discouraged development in many ways. Worse even is the high level of graduate unemployability. It is acknowledged that government has intervened through numerous means including its public-private partnerships such as the SETAs. It is also notable that social entrepreneurs can add value in terms of socioeconomic development of any nation.

The roles of social entrepreneurs in this regard have been examined by a number of researchers in South Africa and beyond. Nevertheless, their particular roles with regard to contributing to graduate employability in South Africa have yet to be investigated. This paper makes a call for further intensive engagement of the subject in the form of an empirical investigation that will seek to decipher how social entrepreneurs can assist in improving graduate employability, thus reducing unemployment and significantly contributing to the socioeconomic development of South Africa. The proposed study will no doubt add to the existing literature on social entrepreneurship and graduate employability.

Nonetheless, this paper may be used to advance the current platforms or grow innovative methods providing graduates a better chance to be successful in the working environment. It is also hoped that this paper will enable social entrepreneurs to specifically evaluate the condition and those abilities essential to employability in the labor market. This will help to understand how South African social entrepreneurs can contribute to social development. This paper calls for sustained discussions on how social entrepreneurs can improve graduate employability.

\section{References}

[1] Abu-Saifan, S., 2012. Social entrepreneurship: definition and boundaries. Technology Innovation Management Review, 2(2), pp.22-29.

[2] Altbeker, A \& Storme, E., 2013. Graduate unemployment in South Africa: a much exaggerated problem. Johannesburg: The Centre for Development and Enterprise. 
[3] Atwood, R., 2010. We can work it out. Times Higher Education, 2nd September. Available at: http://www.timeshighereducation.co.uk/413277. article. [Accessed February 17, 2016].

[4] Austin, M.J. \& Rust, D.Z., 2015. Developing an experiential learning program: milestones and challenges. International Journal of Teaching and Learning in Higher Education, 27(1), pp.143-153.

[5] Bacq, S. \& Janssen, F., 2011. The multiple faces of social entrepreneurship: a review of definitional issues based on geographical and thematic criteria. Entrepreneurship \& Regional Development, 23(5-6), pp.373-403.

[6] Barrie, S.C., 2006. Understanding what we mean by the generic attributes of graduates. Higher Education, 51, pp.215-241.

[7] Bosma, N., Amoros, J.E., 2013. Global Entrepreneurship Monitor 2013 Global Report: fifteen years of assessing entrepreneurship across the globe. Available at: http://www.gemconsortium. org/report. [Accessed 27 January 2016].

[8] Breier, M, \& Erasmus, J., 2009. Skills shortages in South Africa. Case study of key professions. HSRC. Cape Town: South Africa.

[9] Bruns, M., (ed.). Employability of graduate through work-integrated learning (WIL). Available at: http://www.waceinc.org/durban2013/ Refereed\%20Papers/South\%20Africa/Melody \%20Brauns\%20DUT.pdf. [Accessed March 15 2016].

[10] Cape Higher Education Consortium, 2013. Pathways from university to work: a graduate destination survey of the 2010 cohort of graduates from the Western Cape universities. Wynberg: Cape Higher Education Consortium.

[11] City Press., 2012. Young, jobless and desperate - Degrees with no guarantees. Available at: http://www.news24.com/Archives/City-Press/ Young-jobless-and-desperate-Degrees-with-noguarantees-20150429. [Accessed 28 July 2015].

[12] Cleary, M., Horsfall, J., Muthulakshmi, P., Happell, B. \& Hunt G., 2013. Career development: graduate nurse views. Journal of Clinical Nursing, 22 (17-18), p.2605-2613.
[13] Coetzee, M. \& Esterhuizen, K., 2010. Psychological career resources and coping resources of the young unemployed African graduate: an exploratory study [Electronic version]. SA Journal of Industrial Psychology, 36(1), pp.1-19.

[14] Cooper, L., Orrell, J. \& Bowden, M., 2010. Work integrated learning: a guide to effective practice. Routledge; Abingdon.

[15] Dempsey, S.E. \& Sanders, M.L., 2010. Meaningful work? Nonprofit marketization and work/life imbalance in popular autobiographies of social entrepreneurship. Organization, 17(4), pp.437-459.

[16] Duarte, F. \& Hodge, B., 2007. Crossing paradigms: a meta-autoethnography of a fieldwork trip to Brazil. Culture and Organization, 13(3), pp.191-203.

[17] Gartland, K.M.A, \& Wood, E.J., 2008. Research-teaching linkages: enhancing graduate attributes. Sector-wide discussions. Scotland: The Quality Assurance Agency for Higher Education (QAA).

[18] Griesel, H. \& Parker, B., 2009. Graduate Attributes: A baseline study on the South African graduates from the perspective of employers. Pretoria: Higher Education South Africa \& the South African Qualifications Authority.

[19] Helyer, R. \& Lee, D., 2014. The role of work experience in the future employability of higher education graduates. Higher Education Quarter$l y, 68(3)$, pp.348-372.

[20] Hindle, K., 2002. A grounded theory for teaching entrepreneurship using simulation games. Simulation \& Gaming, 33(2), pp.236-241.

[21] Jackson, D. \& Wilton, N., 2016. Developing career management competencies among undergraduates and the role of work-integrated learning. Teaching in Higher Education, 21(3), pp.121.

[22] Jafta, R., 2013. Social entrepreneurship can boost development in $S A$. Available at: http://blogs.sun.ac.za/news/2013/02/07/socialentrepreneurship-can-boost-development-in-sa/. [Accessed March 16 2015].

[23] Karanda, C. \& Toledano, N., 2012. Social entrepreneurship in South Africa: a different narrative for a different context. Social Enterprise Journal, 8(3), 201-215. 
[24] Kirkwood, J. \& Walton, S. (2010). What motivates ecopreneurs to start business? International Journal of Entrepreneurial Behaviour and Research, 16(3), pp.204-228.

[25] Letseka, M., Cosser, M., Breier, M. \& Visser, M., 2010. Student retention and graduate destination: Higher education and labour market access and success. Pretoria: Human Sciences Research Council.

[26] Luppino, A.J., 2007. Minding more than our own business: educating entrepreneurial lawyers through law school-business school collaborations. The Western New England Law Review, 30, p. 151 .

[27] Mader, F.H., Mader, D.R. \& Alexander, E.C., 2015. Job Shadowing Experiences as a Teaching Tool: A New Twist on a Tried and True Technique. Available at: http://digitalcommons. kennesaw.edu/ama_proceedings/2015/Track9/6/. [Accessed March 15, 2016].

[28] Mair, J. \& Noboa, E., 2006. Social entrepreneurship: How intentions to create a social venture are formed. In Social entrepreneurship. United Kingdom: Palgrave Macmillan.

[29] Mair, J., \& Marti, I., 2006. Social entrepreneurship research: a source of explanation, prediction and delight. Journal of World Business, 41, pp.36-44.

[30] Malunga, P., Iwu, CG., \& Mugobo, V.V., 2014. Social entrepreneurs and community development. A literature analysis. Mediterranean Journal of Social Sciences, Vol. 5(16), pp.18-26.

[31] McQuaid, R.W., \& Lindsay, C., 2005. The concept of employability. Urban Studies, 42(2), pp.197-219.

[32] Meyer, C.R. \& Gauthier, J., 2013. Navigating challenging fitness landscapes: social entrepreneurship and the competing dimensions of sustainability. Journal of Social Entrepreneurship, 4(1), pp.23-39.

[33] Minten, S., 2010. Use them or lose them: a study of the employability of sport graduates through their transition into the sport workplace. Managing Leisure, 15, pp.67-82.

[34] Moleke, P., 2006. Employment experiences of graduates. Tshwane: Human Sciences Research Council.
[35] Moleke, P., 2010. The graduate labour market. In: Moeketsi, L., Cosser, M., Breier, M. and Visser, M. (eds). Student retention and graduate destination: Higher education and labour market access and success. Pretoria: Human Sciences Research Council.

[36] Moss, T.W., Short, J.C., Payne, G.T. \& Lumpkin, G.T., 2011. Dual identities in social ventures: An exploratory study. Entrepreneurship Theory and Practice, 35(4), pp.805-830.

[37] Mustar, P., 2009. Technology management education: Innovation and entrepreneurship at MINES ParisTech, a leading French engineering school. Academy of Management Learning \& Education, 8(3), pp.418-425.

[38] NFVF, 2005. An evaluation of film and television training: a learner and graduate perspective. Johannesburg: National Film and Video Foundation.

[39] Oluwajodu, F., Blaauw, D., Greyling, L., \& Kleynhans, E.P.J., 2015. Graduate unemployment in South Africa: Perspectives from the banking sector. SA Journal of Human Resource Management/SA Tydskrif vir Menslikehulpbronbestuur, 13(1) Art. \#656, 9 pages. http://dx.doi.org/10.4102/ sajhrm.v13i1.656.

[40] Oosthuizen, M., 2005. The post-apartheid labour market: 1995-2004. Cape Town, South Africa: Development Policy Research Unit, University of Cape Town.

[41] Open Society Foundation, Mission \& Values. Available at: https://www.opensociety foundations.org/about/mission-values. [Accessed March 18, 2016].

[42] Owens, J., \& Tibby, M., 2014. Enhancing employability through enterprise education: examples of good practice in higher education. York: Higher Education Academy.

[43] Petticrew, M. \& Roberts, H., 2008. Systematic reviews in the social sciences: a practical guide. John Wiley \& Sons.

[44] Pauw, K., Bhorat, H., Goga, S., Ncube, L., Oosthuizen, M. \& Van der Westhuizen, C., 2006. Graduate Unemployment in the Context of Skills Shortages, Education and Training: Findings from a Firm Survey. DPRU Working Paper No. 06/115. 
[45] Ross, J., 2012. \$3bn hit to economy as foreign students slump. The Australian, March 7.

[46] Rozas, L.W. \& Klein, W.C., 2010. The value and purpose of the traditional qualitative literature review. Journal of Evidence-based Social Work, 7(5), pp.387-399.

[47] Santos, F.M., 2012. A positive theory of social entrepreneurship. Journal of Business Ethics, 111(3), pp.335-351.

[48] Sivathanu, B. \& Bhise, P.V., 2013. Challenges for social entrepreneurship. International Journal of Application or Innovation in Engineering \& Management, pp.1-9.

[49] Statistics South Africa, 2013. Quarterly Labour Force survey, quarter 3, 2012. Pretoria, South Africa: StatsSA. Retrieved from https:/www.statssa.gov.za/Publications/P0211/P 02113rdQuarter2012.pdf

[50] StatsSA. (2014). Quarterly Labour Force survey. Pretoria: Statistics South Africa.

[51] Tomlinson, M., 2012. Graduate employability: a review of conceptual and empirical themes. Higher Education Policy, 25(4), pp.407-421.

[52] Trivedi, C., 2010. Towards a social ecological framework for social entrepreneurship. Journal of Entrepreneurship, 19(1), pp.63-80.
[53] Victor, L., 2008. Systematic reviewing. Social research UPDATE, 54(1), pp.1-4.

[54] Weddle, P., 2010. Why employers don't hire perfectly qualified people. Available at: http://www.weddles.com/RSS/Content/wedhpqp .html [Accessed March 12 2016].

[55] Welsh, D.H.B., 2012. The evolution of social entrepreneurship: what have we learned? Journal of Technology Management in China. 7(3), pp.270-290.

[56] Western Cape Government, 2013. Youth development strategy. Available at: https://www.westerncape.gov.za/assets/departme nts/wc-youth-development-strategy.pdf. [Accessed January 25 2015].

[57] Wilson, T., 2012. A review of businessuniversity collaboration. Available at: www.gov.uk/government/uploads/system/upload s/attachment_data/file/32383/12-610-wilsonreview-business-university-collaboration.pdf [Accessed June 18 2015].

[58] Zahra, S.A., Gedajlovic, E., Neubaum, D.O. \& Shulman, J.M., 2009. A typology of social entrepreneurs: motives, search processes and ethical challenges. Journal of Business Venturing, 24(5), pp.519-532. 